\title{
SPIRAL-LAUTAPELI KUNTOUTUKSEN TUKENA
}

Tässä katsauksessa selvitetään kansainväliseen toimintakyvyn, toimintarajoitteiden ja terveyden luokitusjärjestelmään (ICF) pohjautuvan lautapelimuotoisen työkalun (SPIRAL) toimivuutta mielenterveys- ja neuropsykiatrisessa ryhmäkuntoutuksessa. Lisäksi tarkastellaan SPIRAL-lautapelin vaikutuksia GASmuotoisessa tavoitteenasettelussa, kuntoutujien hyvinvoinnin muutoksessa ja kurssimuotoisen kuntoutuksen ryhmäprosessissa. SPIRALmenetelmä on kehitetty Kelan rahoittamassa Tulevaisuus pelissä-hankkeessa.

\section{Johdanto}

Pelilliset innovaatiot ovat lisääntymässä terveydenhuollon konteksteissa (King ym. 2013, Pereira ym. 2014), ja esimerkiksi videopelit täydentävät yksilöllistä kuntoutusta enenevästi (mm. Taylor ym. 2011, Llorens ym. 2015, Vakili \&t Langdon 2016). Lautapelimuotoisia välineitä on aiemmin kehitelty esimerkiksi sairastumiseen sopeutumisen tueksi (Pon 2010) ja kuntoutuksen työkaluiksi sosiaalisten taitojen harjoitteluun (Torres ym. 2002). Niittymäen (2013) opinnäytetyönä Satakunnan ammattikorkeakouluun kehittelemän SPIRAL-lautapelin tarkoituksena on toimia terveydenhuollon ammattihenkilöiden työkaluna silloin, kun on tarpeen konkreettisesti hahmottaa asiakkaan kuntoutuksen tarvetta. SPIRAL-lautapelimenetelmän avulla ryhmämuotoiseen kuntoutukseen osallistuvat kuntoutujat voivat arvioida henkilökohtaisia suoritusja osallistumisrajoitteitaan, psykofyysisiä toimintarajoitteitaan sekä oman tilanteensa kannalta oleellisia ympäristötekijöitä.

Alun perin psykiatriseen kuntoutukseen kehitetystä SPIRAL-menetelmästä jalostet- tiin Tulevaisuus pelissä -kehittämishankkeessa (Koskinen 2015) aiempaa systemaattisempi aikuisille mielenterveyskuntoutujille soveltuva menetelmä sekä erillinen, nuorille autismin kirjon kuntoutujille soveltuva versio. Kehittämistyössä painotettiin toimintarajoitteiden arvioinnin lisäksi kuntoutujan omien muutostoiveiden tunnistamista.

SPIRAL-menetelmä on perinteinen lautapeli, jota pelatessaan kuntoutujat arvioivat oman toimintakykynsä eri osa-alueita kohderyhmäkohtaisten kysymyskorttien avulla erillisille henkilökohtaisille lomakkeille. Pelin päättyessä jokainen pelaaja on tuottanut laaja-alaisen arvion omasta toimintakyvystään sekä nimennyt muutostoiveensa, joista voidaan edelleen johtaa henkilökohtaiset kuntoutumistavoitteet. Kuntoutustyöntekijät voivat hyödyntää SPIRAL-pelissä täytettyjä itsearviointilomakkeita myös muun muassa kuntoutuksen sisällön suunnittelussa, kuntoutujien toimintakyvyn muutosten seuraamisessa ja kuntoutujaa koskevan tiedon siirtämisessä terveydenhuollon yksiköstä toiseen.

Taustalla ICF-luokituksen laaja-alainen näkökulma toimintakykyyn

ICF on WHO:n hyväksymä toimintakyvyn, toimintarajoitteiden ja terveyden kansainvälinen luokitus (THL 2013). ICF-luokituksen viitekehyksessä toimintakyky ja sen rajoitteet käsitetään laaja-alaisesti erilaisten yksilö- ja ympäristötekijöiden vaikutusten alaisena vuorovaikutuksellisena tilana (Harra ym. 2006). ICFluokituksen hyödyntämistä kuntoutustyössä on yleisesti pidetty mahdollisuutena vahvistaa asiakkaan asemaa omassa kuntoutumisprosessissaan (Paltamaa ym. 2011, Pärnä ym. 
2011). ICF-luokitus on juurtunut terveydenhuollon käytäntöihin kuitenkin hyvin hitaasti (Paltamaa \&t Perttinä 2015) muun muassa siksi, ettei valmiita, ICF:n käyttöä helpottavia työkaluja ole ollut saatavilla (Stenberg ym. 2016).

SPIRAL-pelissä toteutettavassa toimintakyvyn arvioinnissa hyödynnetään ICF-luokitusta. SPIRAL-lautapeliin sisältyvät kysymyskortit ja itsearviointilomakkeet ovat kohderyhmäkohtaisia. Mielenterveyskuntoutujien kohdalla toimintakyvyn aihealueet valittiin ICF-luokituksesta depression (Cieza ym. 2004) ja bipolaarihäiriön (Ayuso-Mateos ym. 2013) ydinlistoihin perustuen. Ydinlistoihin on perusteellisen tieteellisen prosessin (Selb ym. 2015) myötä valikoitu näiden kohderyhmien toimintakykyyn oleellisimmin liittyvät ICF-koodit. Neuropsykiatrisille kohderyhmille tekeillä olevat ydinlistaukset (Bölte ym. 2014) eivät peliä kehitettäessä olleet vielä valmistuneet, joten niitä ei voitu hyödyntää. Autismin kirjon kohderyhmälle valittiin sopivia ICF-kuvauskohteita Aspergerin oireyhtymän diagnostisten kriteereiden (ICD-10, WHO 1992) ja kliinisen asiantuntemuksen pohjalta. Molempien kohderyhmien versioihin valittiin aluksi 40 toimintakyvyn osa-aluetta, joista käytännön kokemusten sekä hanketyöryhmän ja kuntoutustyöntekijöiden näkemysten pohjalta lopullisiin versioihin valikoitui 24 parhaiten käytännössä toiminutta toimintakyvyn aluetta.

\section{GAS-menetelmä}

Kuntoutujan aktiivista osallistumista oman kuntoutumisensa suunnitteluun ja seurantaan pidetään tärkeänä kuntoutusinterventiolle asetettujen tavoitteiden saavuttamisen kannalta. Kuntoutujalähtöisten tavoitteiden tunnistaminen edellyttää mielekkäitä ja konkretisoivia välineitä toimintakyvyn itsearviointiin. Kuntoutusintervention tavoitteiden asiakaslähtöisyyttä voidaan pyrkiä lisäämään strukturoidun GAS-menetelmän avulla (Goal Attainment Scaling; Kiresuk \& Sherman 1968). GAS-menetelmässä kuntoutujan kanssa käydyn keskustelun pohjalta kirjataan ylös tavoite tai tavoitteet, jotka kuntoutusintervention kautta halutaan ja voidaan realistisesti saavuttaa. GAS-menetelmässä määritellään asteikko, jolle sijoitetaan hypoteettiset tilanteet, joissa tavoitetaso on joko saavutettu, on jääty sen alapuolelle tai se on ylitetty lievästi tai selvästi.

Sukulan (2013) katsausartikkelissa todetaan, että GAS-menetelmän käyttöönotto Kelan kuntoutuksessa on lisännyt kuntoutujien sitoutumista ja osallistumista kuntoutukseen sekä parantanut kuntoutuksen tavoitteellisuutta ja moniammatillista yhteistyötä. Käytännön kuntoutustyössä GAS-menetelmän käytössä on kuitenkin ilmennyt myös haasteita. Turunen, Hannonen ja Ylisassi (2015) nostavat esiin GAS-menetelmän haasteita erittelevässä artikkelissaan liian yleiselle tasolle tai irrallisiksi jäävät tavoitteet. Ratkaisuksi he tarjoavat kuntoutuksen alussa tapahtuvan tilanneanalyysin napakoittamista sekä riittävän asiantuntijatuen varmistamista. He korostavat työntekijän vastuuta siitä, että kuntoutujalle valikoituvat tavoitteet ovat selkeitä ja merkityksellisiä, mutta muistuttavat, ettei asiantuntijan tehtävänä ole laatia tavoitteita asiakkaan puolesta.

Sukulan (2013) mukaan keskeiset käytännön haasteet ilmenevät tavoitteiden tunnistamisessa sekä tuotettujen tavoitteiden sijoittumisessa kapea-alaisesti tietyille toimintakyvyn osa-alueille. Sukula esittää, että erilaiset kansainväliseen toimintakykyluokitukseen, ICF:ään (THL 2013), perustuvat tavoitteiden kartoittamisen menetelmät voisivat auttaa tunnistamaan toimintakyvyn eri osa-alueille sijoittuvia kuntoutustarpeita paremmin.

\section{SPIRAL-menetelmän edut}

SPIRAL-menetelmällä nähtiin hanketyöryhmässä potentiaalia GAS-muotoisen tavoitetyöskentelyn tukena. SPIRAL-menetelmän ICF:ään pohjautuva lähestymistapa takaa laaja-alaisen näkökulman yksilön toimintakykyyn. Lautapelimuotoinen työkalu on helposti ryhmämuotoiseen kuntoutukseen omaksuttavissa. Lisäksi uskottiin, että toiminnallisen pelin varjolla voisi olla helpompi käsitellä 
sellaisia aiheita, joista keskustelemiseen kuntoutujan voi muutoin olla vaikea motivoitua etenkin kuntoutuksen alkuvaiheessa. Ajatuksena oli, että SPIRAL-peliä pelaamalla tavoitetyöskentelyyn saadaan vaivattomasti konkreettisia kuntoutujalähtöisiä teemoja, ja kuntoutujat aktivoituvat oman kuntoutuksensa rakentajina ikään kuin itsestään.

Toimintakykyosuuden lisäksi lautapelimuotoiseen SPIRAL-menetelmään on sisällytetty erilaisia käyttökokemuksen mielekkyyttä tukevia pelillisiä elementtejä, kuten pisteiden keräämistä ja ryhmätehtäviä. Mielekäs pelitilanne voi sellaisenaan edesauttaa ryhmän yhteistyön toimivuutta ja kohentaa kuntoutusryhmän sisäistä ilmapiiriä. Vuorovaikutusta helpottava toiminnallinen pelitilanne voi myös edistää vertaiskokemusten jakamista kuntoutusryhmässä, parantaa pelaajien itsereflektiota ja kirkastaa käsityksiä omasta hyvinvoinnista ja toimintakyvystä. Optimaalisimmillaan kuntoutuksen alussa käytettävä SPIRAL-peli voisi näin tehostaa kuntoutusintervention vaikutuksia ja korostaa kuntoutujan kokemaa hyvinvoinnin myönteistä muutosta.

SPIRAL-menetelmän käytettävyyttä kuntoutuksessa ja etenkin yksilöllisessä tavoitteenasettelussa tarkasteltiin kehittämistyön yhteydessä. SPIRAL-menetelmää käyttäneiden kuntoutuskurssien lisäksi seurattiin vastaavia kursseja, joilla menetelmä ei ollut käytössä.

Tämän katsauksen tarkoituksena on esitellä kehittämishankkeeseen osallistuneilla kursseilla kartoitettuja kuntoutujien ja työntekijöiden näkemyksiä SPIRAL-menetelmän käytännön toimivuudesta, hyödyistä ja haasteista. Lisäksi katsauksessa raportoidaan systemaattisemman tiedonkeruun tuloksia SPIRAL-menetelmän vaikutuksista. Vertailemalla SPIRALja kontrollikursseilta kerättyjä tietoja pyritään selvittämään, helpottaako SPIRAL-menetelmä GAS-tavoitteiden konkretisoimista, vaikuttaako SPIRAL-menetelmä kuntoutujan hyvinvointiin ja parantaako SPIRAL-menetelmä kuntoutusryhmän koherenssia kuntoutujan näkökulmasta. Tieto uuden menetelmän toimivuudesta voi helpottaa sen käyttöönottoa kuntoutustyöntekijöiden keskuudessa ja näin edistää kehittämishankkeen tuotoksen leviämistä ja juurtumista käytäntöön.

\section{Menetelmät}

\section{Osallistujat ja eteneminen}

SPIRAL-menetelmää kehitettiin sekä aikuisten mielenterveyskuntoutujien että autismin kirjon nuorten kuntoutuskursseilla. Mielenterveyskuntoutujien ryhmässä (MT) oli osallistujia kahdelta taholta: Kuntoutussäätiön kuntoutuspalveluyksikössä toteutettavilta, Kelan tukemilta Askel-kuntoutuskursseilta sekä Lempäälän kunnan psykiatrian yksikössä toteutettavilta mielenterveyskuntoutujien avokuntoutuskursseilta. Autismin kirjon nuorten ryhmä (AS) koostui Mannerheimin Lastensuojeluliiton Lasten ja Nuorten Kuntoutussäätiön järjestämän Aspergerin oireyhtymän sopeutumisvalmennuksen kurssilaisista.

Jokaiselta palveluntuottajalta valittiin kolme mahdollisimman samankaltaista kuntoutusryhmää, jotka toteutuivat vuoden 2015 aikana. Muista poiketen Lempäälän kunnan psykiatrian yksikössä järjestyi kyseisenä ajankohtana vain kaksi keskenään samankaltaista kurssia. Kontrolliryhmäksi päädyttiin siksi valitsemaan eri yksikössä (Ehtookoto Ry) ostopalveluna toteutettava, muutoin samankaltainen ryhmäkuntoutuskurssi. Kehittämishankkeeseen osallistuneita kuntoutusryhmiä oli siis yhteensä yhdeksän. Näistä kuudella SPIRAL-menetelmä oli käytössä (SPIRAL-ryhmät) ja kolmella kuntoutusinterventio toteutettiin kuten tavallisesti, ilman SPIRAL-menetelmää (kontrolliryhmät). Kaikille osallistujille annettiin tietoa hankkeesta ja heiltä pyydettiin kirjallinen suostumus, alaikäisiltä myös huoltajan suostumus.

SPIRAL-ryhmissä menetelmää käytettiin tavanomaisen kurssitoiminnan ohessa ennen kuntoutuksen alkupuolella järjestettäviä yksilöllisiä tavoitekeskusteluja. Mielenterveyskuntoutujien osalta SPIRAL-peliä pelattiin kurssin alussa kahdella peräkkäisellä ryhmäkerralla yhteensä noin kaksi tuntia. Autismin kirjon nuorten kanssa peliä pelattiin sopeu- 
tumisvalmennuskurssin toisena päivänä noin tunnin ajan. Koska menetelmän toimivuutta tarkasteltiin sen kehittämisen yhteydessä, pelin visuaalista ilmettä, sääntöjä ja pelitilannejärjestelyjä muokattiin pelikertojen välillä. Näin ollen pelikokemus ei ollut kaikille muun muassa ajankäytön, ryhmäkoon ja sääntöjen osalta täysin sama. Pelitilanteessa oli läsnä kuntoutuskurssien ohjaajien lisäksi 1-2 vaihtuvaa hanketyöryhmän jäsentä (kuntoutusohjaaja ja/tai psykologi). Kontrollikurssit toteutettiin kuten tavallisesti, ilman hanketyöryhmän jäsenten läsnäoloa.

Kehittämishankkeeseen osallistuneilta kuntoutuskursseilta kerättiin palautetta SPIRAL-menetelmän käyttökokemuksesta ja toimivuudesta kuntoutuksen työkaluna. Sekä kuntoutujat että työntekijät kertoivat näkemyksiään menetelmästä ja sen kehittämiskohteista jokaisen pelitilanteen päätteeksi. Työntekijöitä haastateltiin erikseen myös kurssien jälkeen. SPIRAL-menetelmää kehitettiin jatkuvasti kuntoutujien ja työntekijöiden palautteen pohjalta. Havaintojen ja haastattelujen lisäksi hankkeessa kerättiin systemaattisempaa kyselytietoa. Sekä SPIRAL- että kontrolliryhmissä täytettiin yksilöllisten tavoitekeskusteluiden päätteeksi kysely, jossa arvioitiin tavoitteen määrittämisen sujuvuutta. Lisäksi jokainen osallistuja vastasi hyvinvointia kartoittaviin kyselyihin ensimmäisen kerran ryhmän alussa (T1) ja uudelleen kurssin päätteeksi (T2). Kurssin päätteeksi kuntoutujat arvioivat kuntoutusryhmän ryhmäprosessia itsearviointilomakkeella.

\section{Kuntoutujien ja}

kuntoutustyöntekijöiden haastattelut

Jokaisen pelikerran päätteeksi kuntoutujat ja työntekijät osallistuivat puolistrukturoituun ryhmähaastatteluun, jossa käytiin läpi pelikokemuksen mielekkyyteen ja pelivälineiden toimivuuteen liittyviä teemoja. Mielekkyyden osalta haastattelussa kartoitettiin pelitilanteessa vallinnutta tunnelmaa, ohjeistuksen selkeyttä ja etenemisen sujuvuutta. Pelivälineiden osalta kysyttiin näkemyksiä pelilaudan ominaisuuksista, toimintakykyä koskevien kysymysten sisällöstä ja relevanssista kohderyhmän kannalta, tehtävien mielekkyydestä, itsearviointilomakkeista ja pelin yleisestä ulkoasusta. Lisäksi kussakin kehittämishankkeeseen osallistuneessa kuntoutusyksikössä järjestettiin jälkikäteen puolistrukturoidut työntekijähaastattelut, joihin kutsuttiin SPIRALkursseilla työskennelleet työntekijät. Näissä haastatteluissa kartoitettiin, miten menetelmä asettui kuntoutuskurssin rakenteeseen, miten menetelmään suhtauduttiin myöhemmin kuntoutuksen aikana, helpottiko menetelmä tavoitekeskusteluja, olivatko SPIRAL-ryhmien kuntoutujien tavoitteet jollain tavalla tavanomaisesta poikkeavia sekä sitä, miten menetelmää voisi hyödyntää kuntoutusselosteiden ja -lausuntojen laatimisessa. Lisäksi kerättiin työntekijöiden mielipiteitä menetelmän käytännön toimivuudesta ja menetelmään valittujen toimintakyvyn osa-alueiden osuvuudesta. Kehittämistyön päätyttyä työntekijöille annettiin mahdollisuus arvioida menetelmää vielä kertaalleen hankeyhteistyötä koskeneen sähköisen palautekyselyn yhteydessä.

\section{Kysely GAS-tavoitteen määrittelyn sujuvuudesta}

Seuratuilla kursseilla kuntoutujien tavoitteet asetettiin GAS-menetelmän mukaisesti toteutetuissa yksilöllisissä tavoitekeskusteluissa. Keskustelut käytiin MT-ryhmässä kahden kesken työntekijän ja kuntoutujan välillä ja alaikäisistä koostuvassa AS-ryhmässä työntekijän, kuntoutujan ja tämän huoltajan kesken. Keskustelun päätteeksi sekä kuntoutuja että työntekijä arvioivat tavoitekeskustelun sujuvuutta vastaamalla neljään kysymykseen (taulukko 1).

\section{Kyselyt kuntoutujalle}

Hyvinvointi. MT-ryhmässä seurattiin kuntoutujien mielialaa, elämänlaatua, tyytyväisyyttä elämään sekä hallinnan kokemusta. Mielialaa tutkittiin DEPS-depressioseulalla (Salokangas ym. 1995), joka sisältää 10 asteikolla 0-3 pisteytettyä osiota. Suurempi summapistemäärä tarkoittaa henkilön raportoineen runsaammin 
Taulukko 1. Tavoitekeskustelun sujuvuutta kartoittavat kysymykset.

\begin{tabular}{|lll|}
\hline Arvioija & Kysymys & Skaala \\
\hline Kuntoutuja & Kuinka helppoa kuntoutustavoitteen asettaminen oli? & $1-5$ \\
Kuntoutuja & Kuinka tärkeäksi koet itsellesi asetetun tavoitteen? & $1-5$ \\
Työntekijä & Kuinka helposti kuntoutustavoite löytyi? & $1-5$ \\
Työntekijä & Kuinka kuvailisit kuntoutujan omaa aktiivisuutta tavoitekeskustelussa? & $1-5$ \\
\hline
\end{tabular}

mielialan alavireyttä kuvaavia oireita. Elämänlaatua arvioitiin 26-osioisella WHOQOLBREF-elämänlaatumittarilla (WHOQOL Group 1998), joka sisältää neljä ulottuvuutta (psyykkinen, fyysinen ja sosiaalinen elämänlaatu sekä elinympäristö). Ulottuvuuksille lasketaan pisteet asteikolla 0-100. Lisäksi WHOQOLBREF sisältää kaksi asteikolla 1-5 pisteytettyä kysymystä yleisestä elämänlaadusta ja terveydestä. Tyytyväisyyttä omaan elämään tutkittiin SWLS-itsearviointiasteikolla (Satisfaction With Life Scale; Diener ym. 1985), joka sisältää viisi asteikolla 1-7 pisteytettyä kysymystä ( 1 = täysin eri mieltä, 7 = täysin samaa mieltä). Tyytyväisyyttä elämään kuvataan osioista lasketulla summapistemäärällä. Hallinnantunnetta kartoitettiin SOM-itsearviointiasteikolla (Sense of Mastery; Pearlin \& Schooler 1978), joka sisältää seitsemän asteikolla 1-4 pisteytettyä kysymystä ( 1 = täysin eri mieltä, 4 = täysin samaa mieltä). Hallinnantunnetta kuvataan osioista lasketulla summapistemäärällä.

AS-ryhmässä itsearviointiosuus pyrittiin osallistujien nuoren iän ja taustadiagnoosiin yleisesti liittyvien tarkkaavuusongelmien vuoksi pitämään mahdollisimman suppeana. Hyvinvoinnin osalta AS-ryhmässä seurattiin näin ollen vain terveyteen liittyvää elämänlaatua. Menetelmänä käytettiin 14-17-vuotiaille suunnattua Kiddo-KINDL-itsearviointiasteikkoa (Questionnaire for Measuring HealthRelated Quality of Life in Children and Adolescents, Revised Version; Ravens-Sieberer \&t Bullinger 1998), joka koostuu kuudesta pääteemasta: fyysinen hyvinvointi, tunne-elämän hyvinvointi, itsetunto, perhe, ystävät ja koulu. Osa-alueita kartoitetaan yhteensä 24 kysymyksellä, joita kuntoutuja arvioi asteikolla 1-5. Myöhemmin vastaukset muutetaan asteikolle 0-100. Lisäksi asteikosta on laskettavis- sa yleistä elämänlaadun kokemusta kuvastava kokonaissumma (0-100).

Ryhmäkoherenssi. Kaikki osallistujat (sekä MT- että AS-ryhmä) arvioivat kuntoutusryhmän sisäistä ilmapiiriä ja yhteistyön toimivuutta SOC-G-10-mittarilla (Julkunen ym. 2013), jossa vastaaja arvioi kymmentä väittämää asteikolla 1-5 (1 = ei lainkaan pidä paikkaansa, 5 = pitää täysin paikkansa). Korkea summapistemäärä viittaa vahvaan ryhmän sisäiseen koherenssiin ja vastaajan kokemaan hyvään yhteistyöhön.

\section{Tilastolliset menetelmät}

SPIRAL- ja kontrolliryhmän vertailussa käytettiin parametrisia tilastomenetelmiä silloin, kun se oli jakaumatarkastelujen puitteissa mahdollista. Pienen otoskoon vuoksi joitakin tarkasteluja jouduttiin toteuttamaan vain laadullisesti otoksen tunnuslukuja taulukoimalla. Seurannasta pudonneiden ominaisuuksia tarkasteltiin muuttujakohtaisten katoanalyysien avulla. Kadon systemaattisuutta tarkasteltiin iän ja sukupuolen lisäksi sen mukaan, kuuluiko pois jäänyt henkilö SPIRALvai kontrolliryhmään. Tilastolliseen tiedonkäsittelyyn käytettiin Statistical Package for the Social Sciences (SPSS) -ohjelman versiota 22.0 (IBM Corp., Armonk, NY).

\section{Tulokset}

\section{Osallistujien taustatiedot}

Kehittämishankkeeseen osallistuneita kuntoutujia oli yhteensä 65, joista 46 osallistui SPIRAL-ryhmiin ja loput 19 kontrolliryhmiin (kuva 1). Osallistujien ikä oli keskimäärin $21.2 \pm$ 7 (ka $\pm \mathrm{kh}$ ) vuotta (vaihteluväli 13-45); SPIRAL-ryhmässä $21.7 \pm 7,4$ ja kontrolliryhmässä 


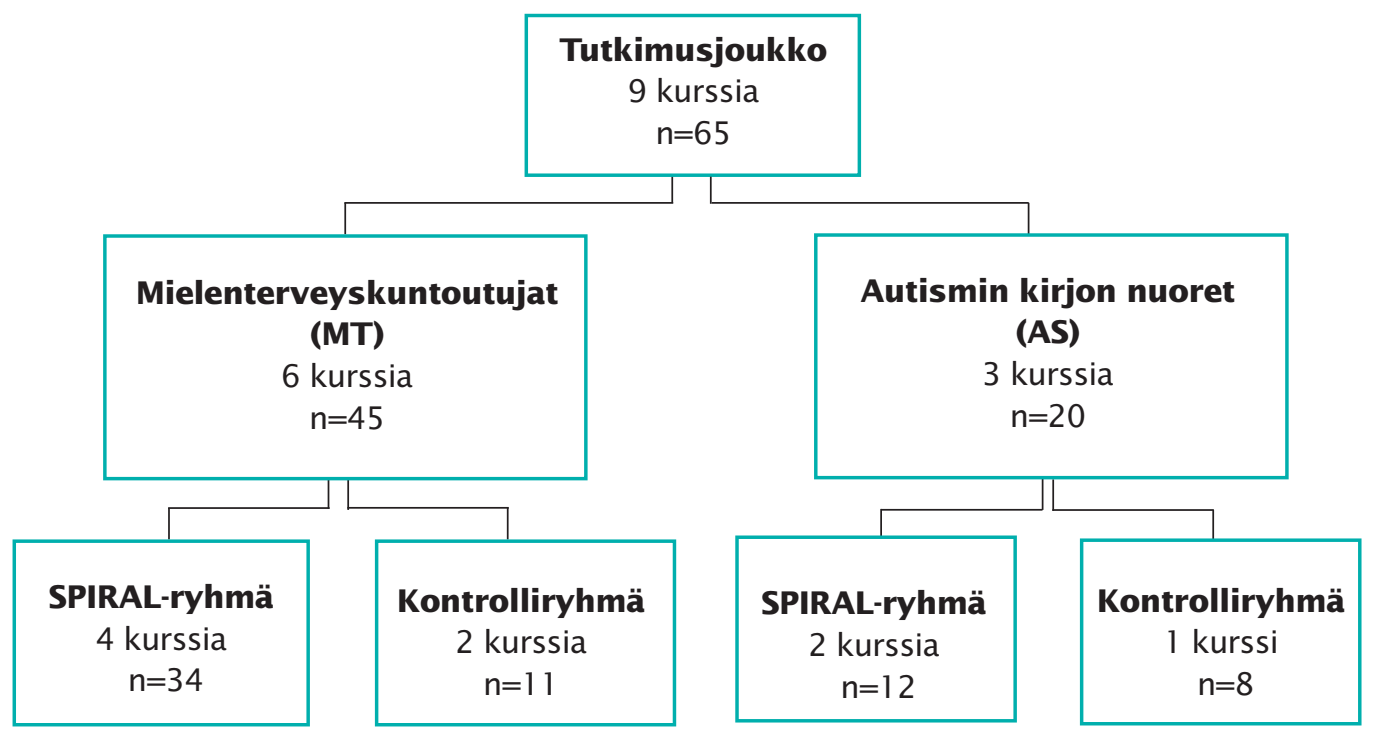

Kuva 1. Osallistujien lukumäärät kohderyhmittäin.

$20.0 \pm 6$. Miehiä tai poikia oli kaikista osallistujista 34 (52 \%); SPIRAL-ryhmästä 25 (54\%) ja kontrolliryhmästä yhdeksän (47 \%). Kunkin ryhmän taustatiedot on esitetty taulukossa 2. Autismin kirjon nuorten SPIRAL-ryhmässä poikien lukumäärä oli muuhun ryhmään ja muihin alaryhmiin nähden korostunut (83 $\%$ ). MT-ryhmässä kuntoutusinterventio keskeytyi kolmella henkilöllä jo ennen tavoitekeskustelua ja lisäksi yhdeltätoista ei saatu seurantavaiheen arvioita (kuva 2). AS-ryhmässä kaikkien kuntoutusinterventio toteutui, mutta kaksi kuntoutujaa ei osallistunut tutkimuksellisen osuuden seurantavaiheeseen.
Kuntoutujien ja työntekijöiden palaute

Pelitilannetta koskeva palaute hyödynnettiin suoraan kehittämistyössä. Muun muassa pelin ulkoasua, sääntöjä, toimintakyvyn osa-alueiden määrää ja toimintakykysisältöjen kieliasua muokattiin jatkuvasti kuntoutujien ja työntekijöiden kommenttien pohjalta paremmin kohderyhmille sopiviksi. Lopulliset SPIRAL-versiot muotoiltiin yhteistyössä työntekijätiimien kanssa.

MT-ryhmän nuoret aikuiset suhtautuivat SPIRAL-peliin pääsääntöisesti positiivisesti, sen sijaan nuorten keskuudessa pelikoke-

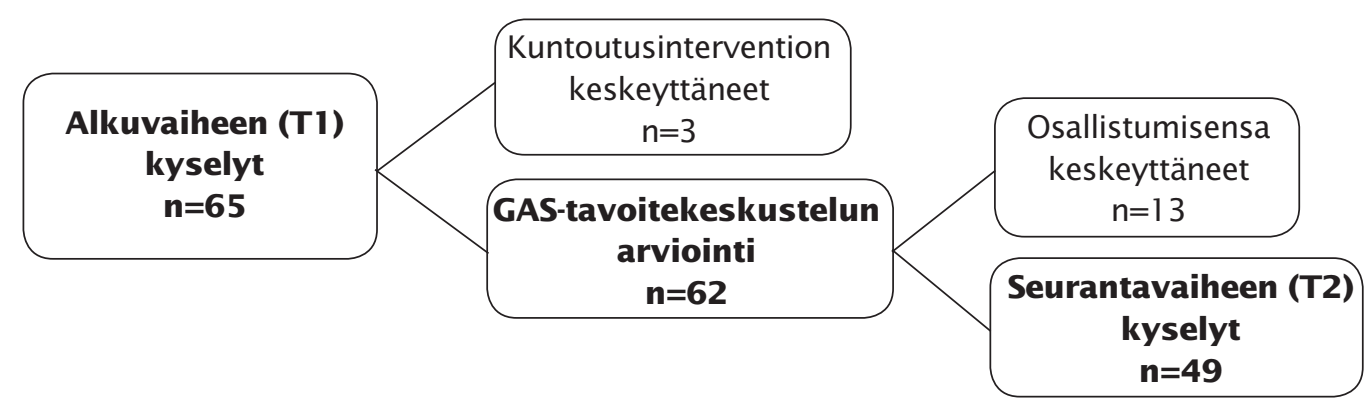

Kuva 2. Kehittämishankkeen tutkimuksellisen osuuden eteneminen ja osallistujat. 
Taulukko 2. Osallistujien taustatiedot.

\begin{tabular}{|llll|}
\hline & Kaikki & SPIRAL-ryhmä & Kontrolliryhmä \\
\hline Aikuiset mielenterveyskuntoutujat & & & \\
\hline $\mathrm{n}$ & $\mathbf{4 5}$ & 34 & 11 \\
Sukupuoli, miesten Ikm (\%) & $\mathbf{2 0 ( 4 4 )}$ & $15(44)$ & $5(46)$ \\
Ikä, ka (kh) & $\mathbf{2 4 . 5 ( 5 . 8 )}$ & $24.5(6.4)$ & $24.6(3.2)$ \\
Koulutus, n (\%) & & & \\
$\quad$ perusaste & $\mathbf{1 2 ( 2 7 )}$ & $10(29)$ & $2(18)$ \\
$\quad$ ammatillinen perustutkinto & $\mathbf{1 2 ( 2 7 )}$ & $8(24)$ & $4(36)$ \\
$\quad$ ylioppilastutkinto & $\mathbf{1 6 ( 3 6 )}$ & $13(38)$ & $3(27)$ \\
$\quad$ alempi korkeakoulu-/opistotutkinto & $\mathbf{4 ( 9 )}$ & $2(6)$ & $2(18)$ \\
ylempi korkeakoulututkinto & $\mathbf{1 ( 2 )}$ & $1(3)$ & - \\
Elämäntilanne, n (\%) & $\mathbf{1 5 ( 3 3 )}$ & $12(35)$ & $3(27)$ \\
$\quad$ opiskelija & $\mathbf{3 ( 7 )}$ & $3(9)$ & - \\
$\quad$ työssä & $\mathbf{7 ( 1 6 )}$ & $5(15)$ & $2(18)$ \\
$\quad$ sairauslomalla & $\mathbf{8 ( 1 8 )}$ & $6(18)$ & $2(18)$ \\
työtön & $\mathbf{1 0 ( 2 2 )}$ & $6(18)$ & $4(36)$ \\
$\quad$ kuntoutustuella & $\mathbf{2 ( 4 )}$ & $2(6)$ & - \\
$\quad$ eläkkeellä & & & 8 \\
\hline Autismin kirjon nuoret & $\mathbf{2 0}$ & 12 & $4(50)$ \\
\hline n & $\mathbf{1 4 ( 7 0 )}$ & $10(83)$ & $13.8(.89)$ \\
\hline Sukupuoli, poikien Ikm (\%) & $\mathbf{1 3 . 7 ( . 8 8 )}$ & $13.6(.90)$ & \\
Ikä, ka (kh) & & & \\
\hline
\end{tabular}

muksessa oli enemmän yksilöllistä vaihtelua. Joillekin AS-ryhmän nuorille pelitilanne oli rankka ja kuormittava, toisille taas liian pitkäveteinen.

Työntekijätapaamisissa AS-ryhmän työntekijät toivat esille, että pelitilanne edellyttää ohjaajan säätelyä. Erityisen tärkeäksi koettiin se, miten peli nuorille esitellään. Yleinen näkemys oli, että SPIRAL-menetelmä tulisi esitellä mahdollisuutena pohtia omaa toimintakykyä ja tavoitteita pelillisesti sen sijaan, että se esiteltäisiin jännittävänä ja viihteellisenä lautapelinä. Kuntoutuksen tueksi suunnitellun työkalun mahdollisuudet kilpailla muiden nuorille varsin tuttujen ja mieluisten pelien joukossa voivat olla heikot. Sekä kuntoutujat että työntekijät kokivat SPIRAL-menetelmän selkeäksi ja helposti omaksuttavaksi.

Yleisesti työntekijät näkivät SPIRAL-menetelmällä mahdollisuuksia tukea kuntoutuksen suunnittelua. Työntekijätapaamisissa tuotiin esille, että kuntoutustyöntekijä pystyy jo pelaamista havainnoimalla saamaan paljon informaatiota kuntoutujasta ja tälle tärkeistä kuntoutumistavoitteista. Työntekijät koki- vat, että pelissä mahdolliset tavoitteet konkretisoituvat kuntoutujille arjessa toimimiseen liittyvien esimerkkien kautta. Kuntoutuksen alussa pelattavan SPIRAL-pelin koettiin aktivoivan tavoitetyöskentelyä ja kuntoutuksessa myöhemmin käsiteltäviä teemoja. Pelissä esiin nousevia teemoja voisi erään AS-ryhmän työntekijän mukaan pyrkiä aktiivisemminkin hyödyntämään kuntoutuskurssin ohjelmassa ja painotuksissa.

Keskeisenä havaintona sekä AS- että MTkurssien työntekijöiden keskuudessa nousi esiin, että SPIRAL-menetelmän avulla kuntoutujan osallisuus omassa kuntoutumisessaan korostuu. Molempien kohderyhmien työntekijät kokivat, että SPIRAL-menetelmä on toimiva keino saada kuntoutuja itse pohtimaan elämäänsä liittyviä asioita ja keskustelemaan niistä. Menetelmän kautta hankittu tieto koettiin hyödylliseksi myös myöhemmin järjestetyissä tavoitekeskusteluissa. AS-ryhmän kohdalla todettiin, että hiljaisenkin nuoren kohdalla keskustelu ja omien mielipiteiden esille tuominen helpottui tavoitekeskustelussa jo siitä, että oli konkreettinen lomake, jota voi- 
Taulukko 3. Tavoitekeskusteluarviointiin osallistuneiden $(n=59)$ ja pois jääneiden $(n=6)$ vertailu taustatekijöiden suhteen.

\begin{tabular}{|lccc|}
\hline & testisuure & df & $p$ \\
\hline ikä, t-testi & -0.067 & 63 & 0.370 \\
sukupuoli, $\chi^{2}$-testi & 0.546 & 1 & 0.460 \\
ryhmä (SPIRAL/kontrolli), $\chi^{2}$-testi & 0.038 & 1 & 0.845 \\
\hline
\end{tabular}

tiin yhdessä nuoren ja tämän perheen kanssa tarkastella. Yleisesti työntekijät kokivat, että GAS-tavoitteen määrittely muuttuu asiakaslähtöisemmäksi, kun pohjalla on asiakkaan itsensä pelin pohjalta nostamat haasteet. Lisäksi koettiin, että SPIRAL ja sen ICF-luokituksen viitekehys tuovat tavoitekeskusteluun laajemman näkökulman ja uusia teemoja.

Lisäksi työntekijät kokivat SPIRAL-menetelmän tukevan ryhmän sisäistä vuorovaikutusta. Ryhmässä tapahtuvan toiminnallisen pelihetken koettiin edistävän tutustumista kurssin alussa. Eräs MT-ryhmän työntekijä toi esille, että pelaaminen on luonteva tapa toimia ryhmässä etenkin silloin, kun kuntoutujalla on sosiaalisten tilanteiden pelkoa ja välttelyä. Yleisesti koettiin, että toiminnallisen pelin varjolla voi olla helpompi keskustella asioista työntekijöiden ja vertaistenkin seurassa.

Työntekijät näkivät uuden menetelmän käyttöönotossa keskeisenä käytännön haasteena sen sovittamisen kuntoutuskurssin rakenteeseen. Kelan standardoimassa kuntoutuksessa GAS-tavoitteet asetetaan hyvin varhaisessa vaiheessa, usein jo ennen ensimmäisiä ryhmäkokoontumisia. Näin ollen SPIRALmenetelmän käyttö tavoitteenasettelun pohjustuksena edellyttää joustoa aikatauluissa. Kehittämishankkeessa kokeiltiin järjestelyä, jossa ryhmäkertoja järjestettiin ennen yksilöllisiä GAS-keskusteluja. Tämä koettiin hyödylliseksi paitsi SPIRAL-kursseilla myös kontrolliryhmissä, joissa tavoitetyöskentelyä kyettiin muilla tavoin pohjustamaan ryhmissä ennen yksilöllistä GAS-keskustelua.

Työntekijöiden palautteissa nousi esille myös se, että myöhemmin tapahtuvassa tavoitekeskustelussa oli helppo keskustella pelissä esiin nousseista asioista SPIRAL-itsearviointilomakkeelle kirjattuja tietoja hyödyntäen, vaikka tavoitekeskustelun työntekijä ei itse olisi ollut läsnä aiemmin toteutuneessa pelitilanteessa. Lisäksi menetelmä koettiin hyödylliseksi tavoitekeskustelussa, vaikka kuntoutuja ei olisi pitänyt varsinaista pelitilannetta mielekkäänä. Tavoitteiden sisällössä työntekijät eivät olleet havainneet merkittävää eroa tavanomaisiin kursseihin verrattuna, mutta he pitivät mahdollisena, että joitain tavoitteisiin nousseita teemoja ei ilman SPIRAL-menetelmää olisi joidenkin henkilöiden kohdalla noussut keskusteluun. Vaikka kehittämishankkeessa SPIRAL-itsearviointilomaketta ei käytetty enää tavoitekeskustelun jälkeen, sen hyödyntämistä kuntoutusselosteissa ja -lausunnoissa ja muussa terveydenhuollon sisällä tapahtuvassa tiedonsiirrossa pidettiin mahdollisena. Yleisesti työntekijät ilmaisivat, että uuden menetelmän käyttöönottoon tulee vaikuttamaan sen käytön helppous, työntekijöiden perehtyneisyys sekä johtoportaan ja koko työyhteisön asenne.

\section{GAS-tavoitekeskustelut}

Kolmen kuntoutusinterventionsa keskeyttäneen lisäksi kolme kuntoutujaa ei osallistunut GAS-keskustelun arviointiin, jolloin arvio tavoitekeskustelun sujuvuudesta saatiin yhteensä 59 (91\%) kuntoutujan GAS-keskustelusta. Kato ei ollut systemaattista taustatekijöiden tai sen mukaan, kuuluiko osallistuja SPIRALvai kontrolliryhmään (taulukko 3). SPIRALryhmässä tavoitekeskustelut arvioitiin kaikkien kysymysten osalta keskiarvotasolla paremmiksi kuin kontrolliryhmässä (kuva 3).

Sekä kuntoutujien että työntekijöiden arvioiden perusteella oli havaittavissa selkeä trendi, jonka mukaan tavoitekeskustelut sujuivat paremmin SPIRAL-ryhmässä kuin kontrolliryhmässä. Trendi ei kuitenkaan saavuttanut tilastollista merkitsevyyttä. Suurimmat 


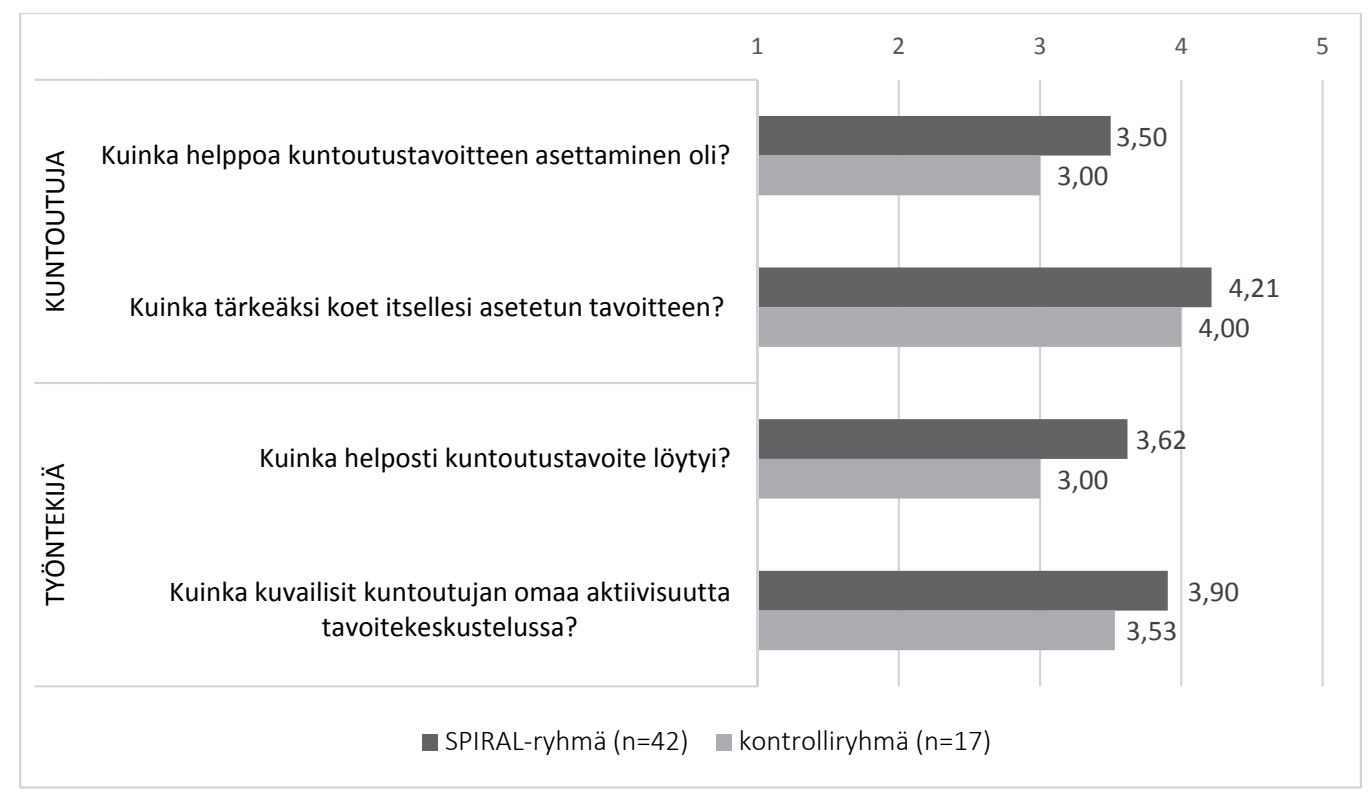

Kuva 3. Kuntoutujan ja työntekijän arvio tavoitekeskustelun sujuvuudesta SPIRAL- ja kontrolliryhmissä.

keskiarvoerot sijoittuivat kysymyksiin, jotka koskivat GAS-tavoitteen määrittelemisen helppoutta. Ryhmäkokojen pienuuden vuoksi tilastollista voimaa vahvistettiin jatkotarkasteluissa yhdistämällä kuntoutujan ja työntekijän tavoitteiden löytymisen sujuvuutta koskevien kysymysten vastaukset. Jatkotarkastelussa SPIRAL-ryhmässä havaittiin tilastollisesti merkitsevästi kontrolliryhmää korkeammat arviot tavoitteen löytymisen sujuvuudesta (3.6 vs. 3.0, $\mathrm{t}(57)=2.48, \mathrm{p}<.05)$.

MT- ja AS-ryhmien tavoitekeskusteluarviot (4 kysymystä) erosivat toisistaan, kun tarkasteltiin SPIRAL- ja kontrolliryhmiä yhdessä (MANOVA $\mathrm{F}(4,53)=6.448, \mathrm{p}<.001)$. Asetettu tavoite koettiin kuntoutujan näkökulmasta tärkeämmäksi MT-ryhmässä kuin AS-ryhmässä (4.4 vs. 3.6, ANOVA F $(1,56)=8.030, \mathrm{p}<.01)$. Työntekijät kokivat kuntoutujan osallistuneen MT-ryhmässä aktiivisemmin tavoitekeskusteluunsa kuin AS-ryhmässä (3.2 vs. 4.1, ANOVA $\mathrm{F}(1,56)=9.019, \mathrm{p}<.01)$. Kun SPIRAL- ja kontrolliryhmien eroja tarkasteltiin erikseen ASja MT-ryhmissä, ryhmien tulokset vastasivat keskiarvotasolla koko joukon tuloksia, mutta eivät saavuttaneet tilastollista merkitsevyyttä.

\section{Kuntoutujan hyvinvointi}

Kun MT-ryhmän katoanalyyseissä verrattiin seurannan ulkopuolelle jääneiden ryhmää seurannassa mukana oleviin, elämänlaadun tai hallinnantunteen alueilla ei havaittu eroja oleellisten taustatietojen osalta (taulukko 4). Kun tarkasteltiin tyytyväisyys elämään -muuttujaa, seurannan ulkopuolelle jääneet olivat seurannassa mukana olevia nuorempia ( $22 \pm 3,5$ vs. $26 \pm 6,1$ v.) (taulukko 4). Mielialaa tarkasteltaessa seurannan ulkopuolelle jääneistä valtaosa (67 \%) oli miehiä, kun taas seurannassa mukana olevat olivat valtaosin naisia (69\%).

AS-ryhmässä seurannasta pudonneita oli niin vähän, ettei yleistä katoanalyysiä tarvittu. AS-ryhmän itsearviointimenetelmän puuttuvien arvojen vuoksi elämänlaatuarviot jäivät kuitenkin etenkin seurantavaiheessa osin puutteellisiksi. Kokonaissumman ja koulua koskevan alaskaalan osalta seuranta-arvio puuttui vastaajista noin 20 prosentin osalta. Seurannan ulkopuolelle jääneet eivät eronneet iän suhteen niistä, joilta seurantatiedot oli mahdollista kerätä elämänlaadun $(\mathrm{t}(16)=$ $-0.033 ; p>.50$ ) tai koulua koskevien arvioiden 
Taulukko 4. MT-ryhmän katoanalyysit hyvinvoinnin osa-alueilla iän (t-testi), sukupuolen $\left(\chi^{2}\right.$ testi) ja ryhmän ( $\chi^{2}$-testi) suhteen.

\begin{tabular}{|llll|}
\hline Hyvinvoinnin osa-alue ja taustatekijä & testisuure & $\mathrm{df}$ & $\mathrm{p}$ \\
\hline Mieliala & & & \\
$\quad$ ikä & -1.933 & 42 & 0.060 \\
$\quad$ sukupuoli & 5.116 & 1 & 0.024 \\
$\quad$ ryhmä (SPIRAL/kontrolli) & 2.548 & 1 & 0.110 \\
Elämänlaatu & -1.511 & 43 & 0.290 \\
$\quad$ ikä & 2.172 & 1 & 0.141 \\
sukupuoli & 0.747 & 1 & 0.387 \\
$\quad$ ryhmä (SPIRAL/kontrolli) & -2.431 & 43 & 0.019 \\
Tyytyväisyys elämään & 3.24 & 1 & 0.072 \\
ikä & 2.167 & 1 & 0.141 \\
sukupuoli & & & \\
ryhmä (SPIRAL/kontrolli) & -2.679 & 43 & 0.204 \\
Hallinnantunne & 0.893 & 1 & 0.345 \\
ikä & 0.059 & 1 & 0.808 \\
sukupuoli & &
\end{tabular}

osa-alueilta ( $\mathrm{t}(18)=0.433, \mathrm{p}>.50)$. Laadullisen tarkastelun perusteella havaittiin, että seurannan ulkopuolelle jäi tasaisesti molempien sukupuolten edustajia sekä SPIRAL- ja kontrolliryhmään alun perin osallistuneita.

T1- ja T2-vaiheissa kuntoutujien raportoimaa hyvinvointia verrattiin SPIRAL- ja kontrolliryhmien välillä muuttujakohtaisin t-testein. T1-vaiheessa tarkasteltiin erikseen kaikkia osallistujia ja erikseen henkilöitä, jotka pysyivät mukana seurannassa. MT-kuntoutujista koostuvan ryhmän kohdalla SPIRALja kontrolliryhmien välillä ei havaittu eroja mielialassa, elämänlaadussa, tyytyväisyydessä elämään tai hallinnantunteessa T1- tai T2vaiheissa. AS-ryhmässä SPIRAL- ja kontrolliryhmien välillä ei ollut eroja T1-vaiheessa. T2-ajankohtana kouluun liittyvät arviot olivat kontrolliryhmässä tilastollisesti merkitsevästi parempia kuin SPIRAL-ryhmässä (62.5 vs. $48.9, \mathrm{t}(13)=-2,179, \mathrm{p}<.05)$. Ero oli jo alkuvaiheessa (T1) melko selkeä (65.8 vs. 51.7), mutta ei tilastollisesti merkitsevä.

Tilastolliset tunnusluvut kuntoutujien raportoimista hyvinvoinnin muutoksista on raportoitu taulukossa 5. MT-ryhmää tarkasteltaessa mieliala-arviot kohenivat seurantajakson aikana $(\mathrm{p}<.05)$, mutta erikseen SPIRALja kontrolliryhmiä tarkasteltaessa erot eivät yltäneet tilastollisesti merkitsevälle tasolle. Yleisessä elämänlaadun kokemuksessa ei MTryhmän seurantajakson aikana havaittu kohenemista. Tyytyväisyys omaan terveyteen sen sijaan koheni $(\mathrm{p}<.05)$. SPIRAL- ja kontrolliryhmiä erikseen tarkasteltaessa vain SPIRALryhmässä havaittiin vastaavaa kohenemista ( $\mathrm{p}<.05)$. Elämänlaadun eri ulottuvuuksia tarkasteltaessa ainoastaan fyysinen elämänlaatu koheni seurantajakson aikana koko MT-ryhmän keskuudessa. Erikseen SPIRAL- ja kontrolliryhmiä tarkasteltaessa merkitseviä muutoksia ei havaittu. Psyykkisessä elämänlaadussa havaittiin SPIRAL-ryhmässä keskiarvotasolla positiivinen muutos, joka lähestyi tilastollista merkitsevyyttä ( $\mathrm{p}=.058)$, mutta kontrolliryhmässä muutosta ei esiintynyt. Tyytyväisyydessä elämään ei MT-ryhmässä havaittu tilastollisesti merkitsevää muutosta seurantajakson aikana. MT-ryhmän hallinnantunne lisääntyi seurantajakson aikana $(\mathrm{p}<.05)$. SPIRAL-ryhmän sisällä muutos ei ollut tilastollisesti merkitsevä, mutta kontrolliryhmässä se pysyi havaittavana $(\mathrm{p}<.05)$.

AS-ryhmässä elämänlaadun kokonaisarviossa tai sen osa-alueissa ei havaittu tilastollisesti merkitsevää muutosta seurannan aikana. Koulua koskevat arviot olivat kuitenkin koko joukossa sekä SPIRAL- ja kontrolliryhmiä 


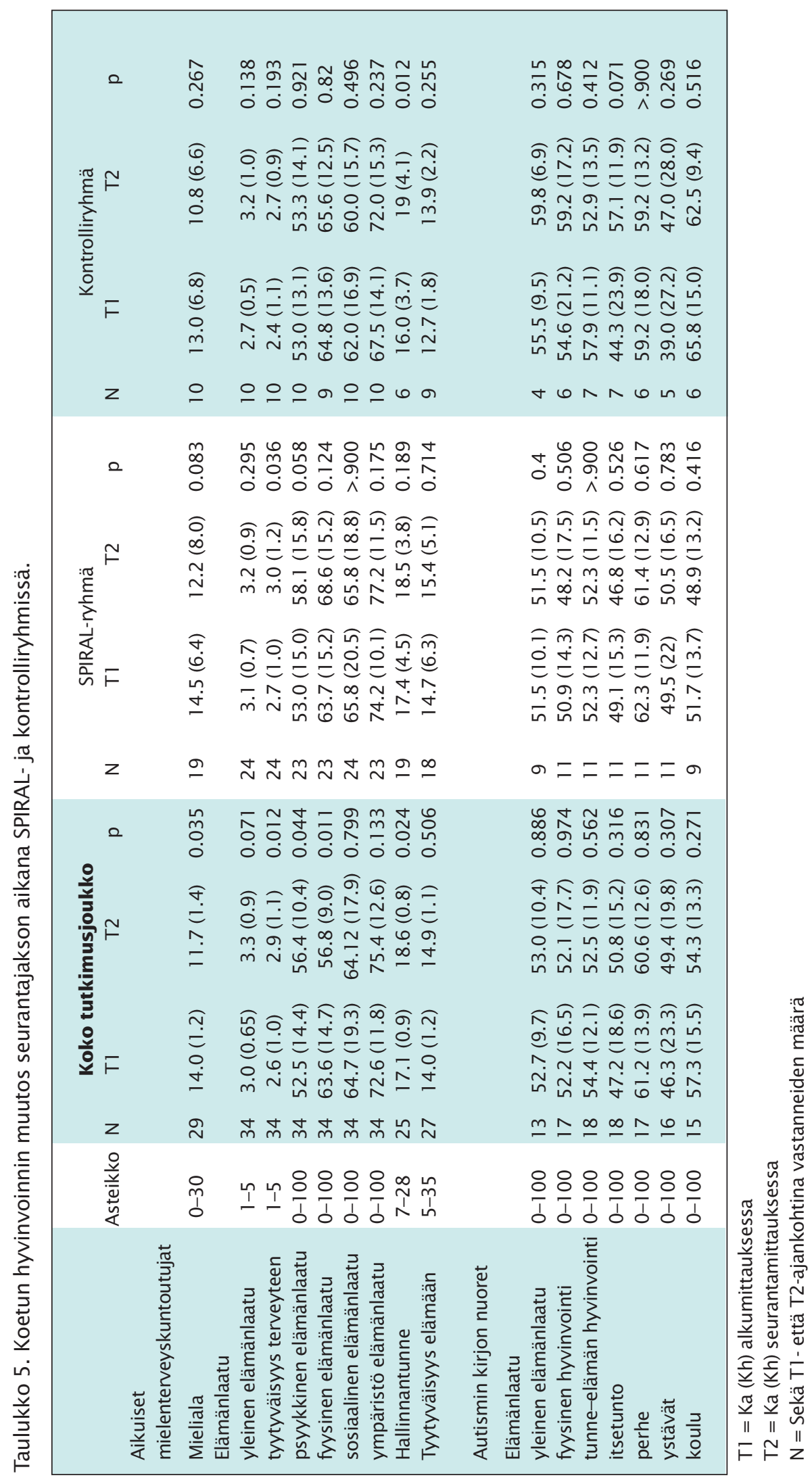


Taulukko 6. Kuntoutujien arvio kuntoutusryhmän koherenssista SPIRAL- ja kontrolliryhmässä.

\begin{tabular}{|lcccccccccc|}
\hline & \multicolumn{3}{c}{ Kaikki osallistujat } & \multicolumn{3}{c}{ SPIRAL-ryhmä } & \multicolumn{3}{c|}{ Kontrolliryhmä } \\
& Vaihteluväli & $\mathbf{N}$ & Md & Vaihteluväli & N & Md & Vaihteluväli & N & Md \\
\hline Kaikki osallistujat & $\mathbf{2 3 - 4 9}$ & $\mathbf{4 8}$ & $\mathbf{3 8 , 0}$ & $23-49$ & 30 & 37,0 & $30-46$ & 18 & 38,5 \\
MT-ryhmä & $\mathbf{2 3 - 4 9}$ & $\mathbf{3 1}$ & $\mathbf{3 9 , 0}$ & $23-49$ & 20 & 38,0 & $34-45$ & 11 & 40,0 \\
AS-ryhmä & $\mathbf{2 8 - 4 6}$ & $\mathbf{1 7}$ & $\mathbf{3 5 , 0}$ & $\mathbf{2 8 - 4 3}$ & 10 & 35,5 & $30-46$ & 7 & 34,0 \\
\hline
\end{tabular}

erikseen tarkasteltaessa T2-vaiheessa matalampia kuin T1-vaiheessa.

\section{Kuntoutujan arvio kuntoutusryhmän koherenssista}

Ryhmäkoherenssiarvio saatiin 48 kuntoutujalta. Kato ei ollut systemaattista iän tai sukupuolen suhteen, mutta valtaosa (94\%) arvioinnin ulkopuolelle jääneistä 17 henkilöstä kuului SPIRAL-ryhmään. SPIRAL- ja kontrolliryhmän välillä ei havaittu tilastollisesti merkitseviä eroja ryhmäkoherenssin kokemuksessa. AS-kuntoutujien SPIRAL-ryhmässä ryhmäkoherenssiarviot olivat mediaaneja (Md) tarkasteltaessa kuitenkin korkeampia kuin kontrolliryhmässä (taulukko 6). SPIRAL-ryhmässä ryhmäkoherenssiarvioiden vaihtelu oli suurempaa kuin kontrolliryhmässä.

\section{Pohdinta}

Tässä katsauksessa pyrittiin tarkastelemaan ICF-pohjaisen lautapelimuotoisen SPIRALmenetelmän soveltuvuutta aikuisten mielenterveyskuntoutujien ja neuropsykiatristen nuorten kuntoutumistavoitteiden pohjustukseen. SPIRAL-menetelmän käytännön toimivuutta, hyötyjä ja haasteita arvioitiin menetelmää käyttäneiden kuntoutujien ja työntekijöiden palautteen pohjalta. Lisäksi vertaamalla SPIRAL- ja kontrollikursseja toisiinsa tarkasteltiin systemaattisesti, helpottaako SPIRALmenetelmä GAS-tavoitteiden konkretisoimista, vaikuttaako SPIRAL-menetelmä kuntoutujan hyvinvointiin ja parantaako SPIRAL-menetelmä kuntoutusryhmän koherenssia kuntoutujan näkökulmasta.

SPIRAL-menetelmä todettiin käyttäjäkokemusten perusteella hyödylliseksi ja helposti omaksuttavaksi välineeksi aikuisten mielenterveyskuntoutujien ja autismin kirjon nuorten ryhmämuotoisessa kuntoutuksessa. Etenkin aikuiset mielenterveyskuntoutujat kokivat pelin pelaamisen mielekkääksi. Työntekijöiden mukaan SPIRAL-menetelmä tukee kuntoutujan osallisuutta GAS-tavoitteen asettelussa ja voi edistää ryhmän sisäistä vuorovaikutusta ja tutustumista. Työntekijän näkökulmasta SPIRAL-pelitilanne voi olla hyödyllinen myös kuntoutusintervention sisältöjen suunnittelun näkökulmasta. Keskeisenä käyttöönoton haasteena työntekijöiden keskuudessa nähtiin pelitilanteen sovittaminen kuntoutuskurssin rakenteeseen, sillä pelaamisen tulisi tapahtua ennen kurssin alussa toteutettavia GAS-tavoitekeskusteluja, mikä ei Kelan kuntoutuksen nykyisten standardien puitteissa ole kuntoutuskursseilla aina mahdollista.

Kun SPIRAL-menetelmää käyttäneitä kursseja verrattiin systemaattisesti vastaaviin kursseihin, joissa menetelmä ei ollut käytössä, tulokset olivat rohkaisevia etenkin GAS-tavoitteen konkretisoimisen osalta. GAS-tavoite löytyi helpommin niissä kuntoutusryhmissä, joissa SPIRAL-lautapeliä käytettiin tavoitekeskustelun pohjustuksena. SPIRAL-menetelmä näyttäisi siis sujuvoittavan kuntoutusintervention tavoitteenasettelua sekä aikuisten mielenterveyskuntoutujien että nuorten autismin kirjon kuntoutujien kohdalla.

Hyvinvoinnin osalta SPIRAL-lautapelin pelaamisella oli viitteellisiä vaikutuksia lähinnä aikuisten mielenterveyskuntoutujien ryhmässä. SPIRAL-peliä pelanneet kokivat elämänlaadussa omaan terveyteen liittyvää osittaista kohentumista seurantajakson aikana toisin kuin ne, jotka eivät olleet pelanneet peliä. Lisäksi vain SPIRAL-menetelmää käyttäneissä ryhmissä havaittiin viitteitä psyykkisen elä- 
mänlaadun kokemuksen kohenemisesta. Vuorovaikutuksellisen ja laaja-alaisesti toimintakykyä kuntoutuksen alkuvaiheessa jäsentävän SPIRAL-menetelmän avulla kuntoutujan on mahdollista tunnistaa myös sellaisia toimintakyvyn alueita, joihin hän on tyytyväinen. Tämä voi vaikuttaa myönteisesti kuntoutujan käsityksiin omasta elämänlaadustaan ja selittää osaltaan SPIRAL-ryhmissä havaittuja ilmiöitä hyvinvoinnissa.

Aikuisten mielenterveyskuntoutujien hallinnantunteen osalta tulokset olivat odotusten vastaisia, sillä hallinnantunteen merkitsevää kohenemista havaittiin vain kontrolliryhmässä. Mielialaan tai elämäntyytyväisyyteen SPIRAL-lautapelin pelaaminen ei vertailujen valossa vaikuttanut. Nämä hyvinvoinnin osa-alueet saattavat liittyä suoremmin kuntoutujan terveydentilaan ja diagnosoidun häiriön oireisiin, joihin SPIRAL-menetelmän kaltaisilla toimintakyvyn arviointia tukevilla välineillä voidaan vaikuttaa erittäin vähän. Sekä SPIRAL-menetelmää käyttäneissä että kontrolliryhmissä mieliala kuitenkin koheni kuntoutusjakson aikana, mikä osoittaa itse kuntoutusinterventiolla olleen selkeitä positiivisia vaikutuksia riippumatta tavoitteiden asettamisen muodosta.

Autismin kirjon nuorten koulua koskevat arviot olivat seurantavaiheessa SPIRALryhmiin verrattuna parempia niissä ryhmissä, joissa SPIRAL ei ollut käytössä. Tämä ero oli ryhmien välillä melko selkeä jo seurannan alussa, mutta ei kuitenkaan tilastollisesti merkitsevä. Sekä SPIRAL- että kontrolliryhmissä koulua koskevat arviot näyttivät pistemääriä tarkasteltaessa heikentyvän seurantajakson aikana, mutta kummankaan ryhmän kohdalla muutokset eivät yltäneet tilastollisesti merkitsevälle tasolle. On mahdollista, että ryhmissä oli koulua koskevissa arvioissa lähtökohtaisia eroja, jotka ovat vaikuttaneet tuloksiin. Kaikkiaan tämän tuloksen merkitys jää epäselväksi ja vaatii jatkotutkimuksia.

Kuntoutujien näkemykset kuntoutusryhmän koherenssista eivät olleet tilastollisesti huomionarvoisesti erilaisia SPIRAL- ja kontrolliryhmissä. Autismin kirjon nuorten kohdalla myönteiset arviot ryhmän ilmapiiristä ja yhteistyöstä olivat kuitenkin jonkin verran yleisempiä niissä ryhmissä, joissa SPIRAL-menetelmä oli käytössä. Kuntoutustyöntekijöiden keskuudessa SPIRAL-menetelmä koettiin vuorovaikutusta helpottavaksi ja ryhmäytymistä edistäväksi työkaluksi.

Yleisesti SPIRAL-menetelmän hyödyt ryhmäprosessin tukena jäivät epävarmoiksi. Työntekijöiden ja kuntoutujien näkökulmat ryhmän arviointiin ovat hyvin erilaiset. Työntekijät kykenivät arvioissaan vertaamaan SPIRAL-kurssien ryhmäprosessia tilanteeseen, jossa SPIRAL-peliä ei ole käytössä, kun taas kuntoutujat arvioivat ainutkertaisen kuntoutusryhmänsä ominaisuuksia kertaluonteisesti kuntoutusintervention jo päätyttyä.

Kaikkiaan ryhmäprosessia arvioitiin tässä hankkeessa varsin rajallisesti. Arvio ryhmäkoherenssista jäi saamatta usealta kuntoutujalta, ja kato painottui SPIRAL-menetelmää käyttäneiden ryhmään. Tämä on voinut vaikuttaa tuloksiin. Etenkin nuorten kuntoutujien voi olla vaikea arvioida ryhmän tunnelmaa ja muita ominaisuuksia kielellistä abstrahointikykyä edellyttävällä itsearviointimenetelmällä. Kaikkiaan työntekijöiden näkemykset rohkaisevat ajattelemaan, että menetelmästä voi olla hyötyä myös kuntoutusryhmän vuorovaikutuksen ja tutustumisen tukena.

Kehittämishankkeessa toteutetun systemaattisen tarkastelun osalta on nostettava esiin joitakin rajoituksia. Tutkimuksellinen osuus toteutettiin osana kehittämishanketta, mikä heikentää tulosten luotettavuutta useasta syystä. SPIRAL-menetelmää kehitettiin samanaikaisesti kahdelle eri kohderyhmälle, jotka poikkesivat toisistaan monin tavoin, muun muassa iän ja taustadiagnoosin osalta. Kohderyhmien tutkimuksellinen seuraaminen vaati tästä johtuen erilaisia lähestymistapoja. SPIRAL- ja kontrolliryhmien väliset vertailut toteutettiin itsearvioidun hyvinvoinnin osalta kiinnostuksen kohteena olevissa kahdessa kohderyhmässä eri menetelmillä. Näin ollen SPIRAL- ja kontrolliryhmät jäivät hyvinvoinnista kerätyn tiedon osalta valitettavan pieniksi. Tämän lisäksi analyyseihin päätyneiden joukon kokoa rajoitti pitkittäisasetelmissa väistämättä esiintyvä kato sekä itsearviointi- 
lomakkeiden puutteellinen täyttö.

Samanaikaisessa kehittämistyössä menetelmän visuaalista ilmettä, sääntöjä ja pelitilannejärjestelyjä muokattiin aiempien kokemusten perusteella ryhmien välillä. Näin ollen pelikokemus saattoi olla jossain määrin erilainen tutkimuksellisen osuuden alussa osallistuneilla kuin myöhemmissä vaiheissa pelanneilla, mikä lisäsi SPIRAL-ryhmien heterogeenisuutta. Lisäksi kontrollikurssit toteutettiin kuten tavallisesti, ilman SPIRAL-työryhmän jäsenten läsnäoloa, jolloin on mahdollista, että ylimääräisten henkilöiden läsnäolo tai lautapelitilanne sinänsä vaikutti tuloksiin.

Viimeisenä huomionarvoisena seikkana on mainittava, että autismin kirjon nuorten SPIRAL-ryhmissä pojat olivat yliedustettuina. Epätasapainoinen sukupuolijakauma voi siten autismin kirjon nuorten kohdalla osaltaan vaikuttaa systemaattisten vertailujen tuloksiin. SPIRAL- ja kontrolliryhmät olivat taustatekijöiden suhteen muutoin varsin tasapainoisesti jakautuneet, eikä seurannan aikana tapahtuneessa kadossa havaittu oleellista systemaattisuutta.

\section{Lopuksi}

Katsauksessa esiteltyjen havaintojen pohjalta ICF-pohjainen SPIRAL-menetelmä on käytännössä toimiva työkalu sekä aikuisten mielenterveyskuntoutujien että autismin kirjon nuorten kuntoutuksessa. Kuntoutuskursseilta kerätyn palautteen perusteella SPIRAL-lautapelin avulla voidaan toteuttaa yksilöllistä toimintakyvyn itsearviointia ryhmissä ja näin sujuvoittaa kuntoutuksen tavoitetyöskentelyä. Systemaattisten vertailujen pohjalta SPIRALmenetelmä näyttää helpottavan GAS-tavoitteiden konkretisoimista ja saattaa vaikuttaa aikuisten mielenterveyskuntoutujien elämänlaatuun suotuisasti. Kuntoutujan arvioon kuntoutusryhmän koherenssista SPIRAL-menetelmällä ei havaittu vaikutuksia, mutta kuntoutustyöntekijät pitivät menetelmää hyödyllisenä myös ryhmäytymisen näkökulmasta.

Menetelmä vastaa osaltaan konkreettisten ICF-pohjaisten työkalujen tarpeeseen ja GASmenetelmän käytössä todettuihin haasteisiin
(Sukula 2013, Turunen ym. 2015). Uuden menetelmän toivotaan juurtuvan käytäntöön ja tukevan yksilöllistä ja asiakaslähtöistä kuntoutustyötä, jolle sillä on tässä katsauksessa raportoitujen tulosten pohjalta selkeät edellytykset. Keskeisimpänä käyttöönoton haasteena vaikuttaisi olevan uuden menetelmän sovittaminen kuntoutuskurssin rakenteeseen ja aikatauluihin.

Jatkossa kehittämistyön myötä viimeistellyn, valmiin SPIRAL-menetelmän vaikutuksia on tarpeen tutkia systemaattisemmin ja isommissa ryhmissä. Tavoitteen määrittelyn sujuvuuden lisäksi olisi mielenkiintoista tarkastella systemaattisesti, vaikuttaako ICF-pohjainen työkalu GAS-tavoitteiden sisältöön ja esimerkiksi siihen, miten ajankäyttö jakautuu kuntoutusintervention sisällä.

Pelivälineet ovat vapaasti tulostettavissa osoitteessa www.kuntoutussaatio.fi/spiral. Sivustolla on myös kattavat ohjeet menetelmän käyttöönoton tueksi.

Kiitokset: Työ on toteutettu Kansaneläkelaitoksen tuella.

Johanna Stenberg, PsM, tutkija, Kuntoutussäätiö

Viliina Rantaniska, PsM, tutkija,

Kuntoutussäätiö

Kirsi Niittymäki, YAMK, kuntoutusohjaaja, tutkija, Kuntoutussäätiö

Mari Saarinen, PsL, neuropsykologian erikois-
psykologi, MLL:n Lasten ja Nuorten Kuntoutussäätiö

Erja Poutiainen, FT, dosentti, johtava tutkija, Kuntoutussäätiö

\section{Lähteet}

Ayuso-Mateos JL, Ávila CC, Anaya C, Cieza A, Vieta E (2013) Development of the International Classification of Functioning, Disability and Health core sets for bipolar disorders: results of an international consensus process. Disability \&t Rehabilitation 35, 25, 2138-2146.

Bölte S, Schipper E, Robison JE, Wong VC, Selb M, Singhal N, ..., Zwaigenbaum L (2014) Classification of functioning and impairment: the development of ICF core sets for autism spectrum disorder. Autism Research 7, 1, 167-172. 
Cieza A, Chatterji S, Andersen C, Cantista P, Herceg M, Melvin J, ..., de Bie R (2004) ICF Core Sets for depression. Journal of Rehabilitation Medicine 36, 0, 128-134.

Diener E, Emmons RA, Larsen RJ, Griffin S (1985) The Satisfaction with Life Scale. Journal of Personality Assessment, 49, 71-75.

Harra T, Aralinna V, Heikkilä M, Korkiatupa R, Löytönen K, Onkalo-Okkonen R (2006) Kohti toimintakyvyn kokonaisvaltaista arviointia. Duodecim 122, 554-62.

Julkunen J, Pietilä P, Gustavsson-Lilius M (2013) Kuntoutusryhmän koherenssin arviointi: kyselymenetelmän luotettavuus ja alustavia tuloksia validiteetista. Kuntoutus 3, 5-19.

King D, Greaves F, Exeter C, Darzi A (2013) 'Gamification': Influencing health behaviours with games. Journal of the Royal Society of Medicine 106, 3, 76-78.

Kiresuk TJ, Sherman MRE (1968) Goal attainment scaling: A general method for evaluating comprehensive community mental health programs. Community Mental Health Journal 4, 6, 443-453.

Koskinen J (2015) Tulevaisuus pelissä: ICF-pohjainen lautapeli kuntoutuksen suunnannäyttäjänä. Kuntoutus 2, 66-70.

Llorens , Noé E, Ferri J, Alcañiz M (2015) Videogamebased group therapy to improve self-awareness and social skills after traumatic brain injury. Journal of neuroengineering and rehabilitation 12, 1, 1.

Niittymäki K (2013) Spiral - kuntoutuksen spiraali: ICF-pohjainen lautapeli mielenterveyskuntoutukseen. Opinnäytetyö, Satakunnan Ammattikorkeakoulu, Pori.

Paltamaa J, Karhula M, Suomela-Markkanen T, AuttiRämö I (2011) Hyvän kuntoutuskäytännön perusta. Käytännön ja tutkimustiedon analyysistä suosituksiin vaikeavammaisten kuntoutuksen kehittämishankkeessa. Kelan tutkimusosasto, Helsinki.

Paltamaa J, Perttinä P (toim.) (2015) Toimintakyvyn arviointi. ICF teoriasta käytäntöön. Helsinki: Kela, Sosiaali- ja terveysturvan tutkimuksia 137.

Pärnä K, Saarinen M, Mellenius N, Antikainen P (2011) ICF ja perhekuntoutuksen arviointi. Kuntoutus 3, 12-21.

Pearlin LI, Schooler C (1978) The structure of coping. Journal of Health and Social Behavior 24, 2-15.

Pereira P, Duarte E, Rebelo F, Noriega P (2014) A Review of Gamification for Health-Related Contexts. Teoksessa A Marcus (toim.) Design, User Experience and Usability. User Experience Design for Diverse Interaction Platforms and Environments. Springer International Publishing, 742-753.

Pon AK (2010) My Wonderful Life: A board game for patients with advanced cancer. Illness, Crisis, \&t Loss 18, 2, 147-161.

Ravens-Sieberer U, Bullinger M (1998) Assessing health-related quality of life in chronically ill children with the German KINDL: first psychometric and content analytical results. Qual Life Res, 7, 5, 399-407.

Salokangas RK, Poutanen 0, Stengård E (1995) Screening for depression in primary care. Development and validation of the Depression Scale, a screening instrument for depression. Acta Psychiatrica Scandinavia 92, 1, 10-16.

Selb M, Escorpizo R, Kostanjsek N, Stucki G, Ustün B, Cieza A (2015) A guide on how to develop an international classification of functioning, disability and health core set. European journal of physical and rehabilitation medicine 51, 1, 105-117.

Stenberg J, Rantaniska V, Niittymäki K, Yli-Kaitala H, Poutiainen E, Saarinen M (2016) ICF-luokitusjärjestelmän rooli terveydenhuollon asiakastyössä. Kuntoutus 1, 74-76.

Sukula S (2013) Hyvin laaditut tavoitteet ovat kuntoutuksen selkäranka. Kuntoutus 2, 41-48.

Taylor MJ, McCormick D, Impson R, Shawis T, Griffin M (2011) Activity Promoting Gaming Systems in Exercise and Rehabilitation. Journal of rehabilitation research and development 48, 10, 1171-1186.

THL (2013) Toimintakyvyn, toimintarajoitteiden ja terveyden kansainvälinen luokitus ICF. Helsinki: Terveyden ja hyvinvoinnin laitos.

Torres A, Mendez LP, Merino H, Moran EA (2002) Rehab Rounds: Improving Social Functioning in Schizophrenia by Playing the Train Game. Psychiatric Services 53, 7, 799-801.

Turunen J, Hannonen K, Ylisassi H (2015) Mikä GASmenetelmässä työvälineenä haastaa ja mikä tuntuu helpolta? Artikkelikokoelmassa Sukula S, Vainiemi K, Laukkala T (toim.) GAS. Menetelmästä sovellukseen.

Vakili A, Langdon R (2016) Cognitive rehabilitation of attention deficits in traumatic brain injury using action video games: A controlled trial. Cogent Psychology 3, 1, 1-13.

WHOQOL Group (1998) Development of the World Health Organization WHOQOL-BREF quality of life assessment. Psychol Med May 28, 3, 551-558. WHO (1992) The ICD-10 classification of mental and behavioural disorders: clinical descriptions and diagnostic guidelines. Geneva: World Health Organization. 